\title{
Dokumentowanie geologiczno-inżynierskie osuwisk na terenie fliszu karpackiego
}

\author{
Jarosław Kos ${ }^{1}$, Antoni Wójcik ${ }^{1}$
}

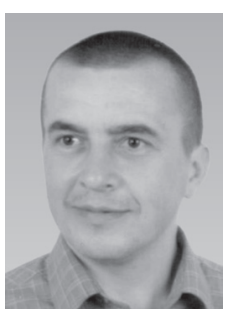

J. Kos

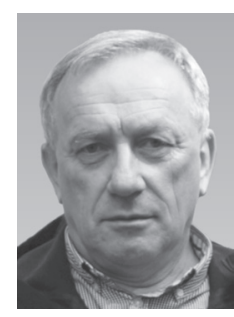

A. Wójcik

Geological and engineering documentation of landslides in the Carpathian flysch. Prz. Geol., 69: 825-834; doi: 10.7306/2021.44

A b s tract. When conducting geological surveys in landslide areas, it is important to define the scope of the planned geological works. The most important issue in the study of landslides is the recognition of the depth and shape of the slip surface. This requires the correct type of drilling and a good core quality. Most often, within a single landslide, several slip surfaces are documented, which occur at different depths, which is associated with a complex manner of motion and shear. Proper determination of the deepest sliding surfaces allows for the construction of a calculation model and selection of the optimal method of securing the landslide area. The course of the slip surface is often not determined by the depth of the bedrock under the cover formations. Geological diagnosis should depend on the size of the examined landslide and the impact of its activation on potential damage / destruction of existing buildings and technical infrastructure. The method of documenting and carrying out calculations is presented as recommended in landslide areas. In the first step, calculations should be made on the basis of data obtained from field work and parameters obtained from laboratory tests. Monitoring should complement field research and assess the scale of displacements. Conducting stability calculations should be a standard for the preparation of geological and engineering documentation of landslides and areas at risk of mass movements. It allows you to assess the risk and threats to the planned investment or protective structure. This is to provide permanent safeguards to prevent damage to buildings that have been designed on the basis of uncertain geological data. It is postulated to modify the ordinance on the implementation of geological and engineering documentation by adding a point concerning the documentation of landslides. If there is such an area, special requirements must be met when conducting geological surveys.

Keywords: mass movements, landslide, Maków landslide, landslide design procedure, Carpathian flysch, southern Poland

Powierzchniowe ruchy masowe stanowią istotne zagrożenie geodynamiczne $\mathrm{w}$ południowej części Polski (Chowaniec, Wójcik, 2012; Wójcik i in., 2019). Najbardziej niekorzystne dla działalności antropogenicznej są tereny osuwisk, których uruchomienie powoduje znaczne straty ekonomiczne (Rączkowski, 2015). Po uruchomieniu osuwiska i wystąpieniu zniszczeń przeprowadza się szczegółowe badania geologiczne na terenach, gdzie planuje się wykonanie zabezpieczeń konstrukcyjnych i prac budowlanych (Grabowski i in., 2008). W trakcie prowadzenia badań geologicznych i wykonywania projektu budowlanego stosuje się różne metody obliczenia stateczności stoku. Istotnym elementem jest właściwe udokumentowanie parametrów geologiczno-inżynierskich, które stanowią podstawę do obliczeń stateczności.

W Polsce rejonem najbardziej predysponowanym do występowania osuwisk są Karpaty (Bober, 1984; Poprawa, Rączkowski, 2003), czemu sprzyja charakter rzeźby terenu i budowa geologiczna (naprzemianległe występowanie piaskowców i łupków oraz zaburzenia tektoniczne). Poza obszarem Karpat osuwiska występują głównie w obrębie zboczy większych dolin rzecznych, wzdłuż klifowego wybrzeża Bałtyku, a także na obszarach pokrytych miąższymi pokrywami lessów i na terenach o rzeźbie młodoglacjalnej. Wprowadzanie nowych metod kartograficznych pozwoliło na stwierdzenie wielokrotnie większej liczby osuwisk na terenie Sudetów niż dotychczas przyjmowano (Migoń, Kasprzak, 2011; Migoń i in., 2014; Sikora, Wojciechowski, 2019).
Na podstawie osuwiskowej bazy danych SOPO oraz wybranych kryteriów geologicznych i morfometrycznych, opracowano mapę podatności osuwiskowej Polski (Wojciechowski, 2019), z której wynika, że blisko $20 \%$ terenu Polski można uznać za istotne z punktu widzenia podatności osuwiskowej. Tereny o bardzo dużej podatności znajdują się na obszarze Karpat. Dużą podatnością osuwiskową charakteryzują się wyżyny: Śląska, Krakowska, Małopolska i Lubelska, a także niektóre tereny Sudetów (m.in. Góry Bardzkie i Góry Kamienne) oraz strefy zboczy dolin rzecznych.

W celu dokumentowania geologiczno-inżynierskiego wykonywano liczne instrukcje oraz wytyczne, a także opisywano szczegółowe przypadki osuwisk (Instrukcja, 1999; Wytyczne, 2016; Wójcik, Kos, 2017; Wójcik i in., 2017; Kos, 2019). Wykonano także kompleksowe opracowanie, w którym zaproponowano rozstawy wierceń, zakres badań laboratoryjnych oraz metody prowadzenia badań geologiczno-inżynierskich na osuwiskach (Frankowski i in., 2012).

Dokumentowanie geologiczno-inżynierskie w obrębie fliszu karpackiego, ze względu na znaczne obszary osuwisk i rodzaje projektowanych inwestycji, wymaga indywidualnego podejścia. Rozpoznanie geologiczne na takich obszarach służy celom inwestycyjnym i osuwiska powinny być szczegółowo rozpoznane przede wszystkim $\mathrm{w}$ tych rejonach, w których jest przewidywane ich zabezpieczenie. Takie rozpoznanie wymaga specyficznego podejścia ze względu na skalę zagrożeń i skutki wynikające z nie-

\footnotetext{
${ }^{1}$ Państwowy Instytut Geologiczny - Państwowy Instytut Badawczy, Centrum Geozagrożeń, ul. Skrzatów 1, 31-560 Kraków; jkos@pgi.gov.pl, awojc@pgi.gov.pl
} 
właściwego udokumentowania geologiczno-inżynierskiego, w szczególności określenia głębokości i przebiegu powierzchni poślizgu.

\section{METODY BADAŃ}

W celu analizy uwarunkowań środowiskowych przeprowadza się prace kameralne, w tym analizę literatury oraz opracowań archiwalnych na podstawie wykonanych dokumentacji geologicznych oraz materiałów kartograficznych. Prowadzi się także powierzchniowe i wgłębne pomiary monitoringowe. Dla obszaru osuwiskowego powinny zostać wykonane badania i analizy zgodnie ze schematem:

- prace terenowe (kartowanie geologiczno-inżynierskie, wiercenia badawcze, pobór próbek gruntów i skał, instalacja kolumn inklinometrycznych i założenie sieci monitoringu powierzchniowego oraz wgłębnego, badania geofizyczne dużych osuwisk),

- kompleksowe badania laboratoryjne,

- pomiary inklinometryczne i monitoring powierzchniowy,

- obliczenia stateczności dla wybranych przekrojów obliczeniowych,

- dokumentacja geologiczno-inżynierska.

Najważniejszą kwestią podczas prowadzenia badań jest odpowiednia technika wykonywania wierceń. Powinny to być pełnordzeniowane otwory wiertnicze wykonywane przynajmniej podwójnym aparatem rdzeniowym, z ciągłym poborem rdzenia. Wymagany uzysk rdzenia nie powinien być mniejszy niż $85 \%$. Rdzenie należy zabezpieczyć przed zawilgoceniem lub wyschnięciem poprzez szczelne owinięcie folią, a próbki należy pobierać metodą A do plastikowych pojemników. Badania laboratoryjne powinny obejmować: określenie rodzaju gruntu, jego wizualnych cech fizycznych, domieszek, a także oznaczenie stanu konsystencji, zagęszczenia oraz parametrów wytrzymałościowych. Nawiercone utwory skaliste powinny być szczegółowo opisywane poprzez określenie rodzaju skały, stopnia spękania i zwietrzenia, rodzaju spękań i stopnia ich wypełnienia oraz obecności przewarstwień (Pinińska, 2003, 2004, 2007). Opis i klasyfikację nawierconych gruntów i skał należy prowadzić na podstawie norm PN-EN 1997-1 i PN-EN 1997-2 Eurokod 7 wraz z załącznikami.

Przemieszczenia wgłębne (monitoring) osuwisk są prowadzone przy wykorzystaniu inklinometrów. Pozwalają one na określenie tempa, kierunku i głębokości przemieszczania koluwiów osuwiskowych. Szczegóły montażu, sposobów pomiarów oraz obliczeń są zawarte w instrukcjach, a wcześniej zostały opracowane przez Turnera i Schustera (1996), Nescieruka i Rączkowskiego (2012), Zabuskiego (2013), Nescieruka $(2015,2017)$ oraz zawarte na stronie internetowej Państwowego Instytutu Geologicznego (PIG-PIB) https://www.pgi.gov.pl/osuwiska/sopo-baza-wiedzy/6330-metody-wglebne.html.

Po wykonaniu badań dla osuwisk powinny zostać przeprowadzone obliczenia stateczności, w których powierzchnia poślizgu będzie modelowana na podstawie danych z prac terenowych i badań laboratoryjnych. Klasyczną metodą analizy osuwisk jest korzystanie z warunków statycznej równowagi - analizuje się równowagę sił i określa wskaźnik stateczności SF (Wysokiński, 2011). Dla osuwisk skomplikowanych i wielkoobszarowych powinny zostać wykorzystane metody elementów skończonych (MES) lub metody różnic skończonych (MRS) (Zabuski, Kulczykowski, 2020). Obliczenia MES wykonuje się najczęściej na podstawie konstytutywnego modelu gruntu Coulomba-Mohra z wykorzystaniem metody redukcji parametrów wytrzymałościowych. W metodzie MRS obliczane są naprężenia i przemieszczenia dla sprężystego lub sprężysto-plastycznego modelu ośrodka.

\section{BADANE OSUWISKA}

Przykłady wykonywania przekrojów obliczeniowych podano na konkretnych osuwiskach zlokalizowanych w Makowie Podhalańskim oraz Brzyczynie (ryc. 1). Wybrano osuwiska o różnej wielkości.

Osuwisko w Makowie Podhalańskim, uaktywnione w 2001 r., znajduje się po wschodniej stronie doliny Skawy, na północno-zachodnim stoku Łysej Góry (Pasmo Kotonia) (ryc. 1, 2). Osuwisko rozpoczyna się wyraźnie widoczną w terenie skarpą osuwiskową tworzącą dwie połączone półkoliste nisze o wysokości maksymalnej 6-10 m i nachyleniu $30^{\circ}$. Całość terenu poniżej skarpy głównej jest pofalowana, z licznymi niszami wtórnymi i progami wewnątrzosuwiskowymi oraz skarpami wtórnymi i bocznymi o wysokości do $8 \mathrm{~m}$ (ryc. 2). Fragment zachodniej części osuwiska jest ograniczony potokiem będącym prawym dopływem Skawy. Osuwisko nasuwa się na aluwia Skawy wyraźnym czołem o zmiennej wysokości sięgającej miejscami do 4-13 m i jest częściowo przekształcone, co wynika z lokalizacji w jego rejonie budynków mieszkalnych i gospodarczych oraz drogi gminnej. Jest to osuwisko skalno-zwietrzelinowe i ma charakter zsuwu translacyjno-rotacyjnego. Powierzchnia osuwiska wynosi ponad 10,0 ha, a miąższość koluwium w jego centralnej części przekracza 40 m (Kos i in., 2016) (ryc. 3, 4). Osuwisko jest położone w obrębie płaszczowiny magurskiej, w jego podłożu nawiercono łupki pstre, piaskowce ciężkowickie, warstwy hieroglifowe oraz piaskowce magurskie. Zainstalowano trzy kolumny inklinometryczne, które dokumentowały przemieszczenia wgłębne.

W celu rozpoznania warunków geologicznych na terenie osuwiska wykonano 8 otworów geologiczno-inżynierskich o głębokości od 10,0 do 45,0 m (ryc. 3, 4). Była ona uzależniona od stwierdzenia występowania płaszczyzny poślizgu. Głębokości głównych powierzchni ścięcia stwierdzanych podczas analizy rdzeni wiertniczych zawierały się w przedziale $3,7-42,3 \mathrm{~m}$. Wydzielono górną warstwę koluwiów na głębokości od 3,7 do 13,0 m oraz głęboką, obejmującą przemieszczenia na głębokości do 42,3 m. Głęboka powierzchnia poślizgu obejmuje pakiety skalne piaskowców i łupków, które uległy przemieszczeniu.

Osuwisko w Makowie Podhalańskim to przykład dużego obszaru, który udokumentowano z wykonaniem dwóch przekrojów wzdłuż osi osuwiska oraz przekrojów poprzecznych. Pozwoliło to na określenie głębokich płaszczyzn poślizgu i w ostateczności rezygnacji z trwałego za- 


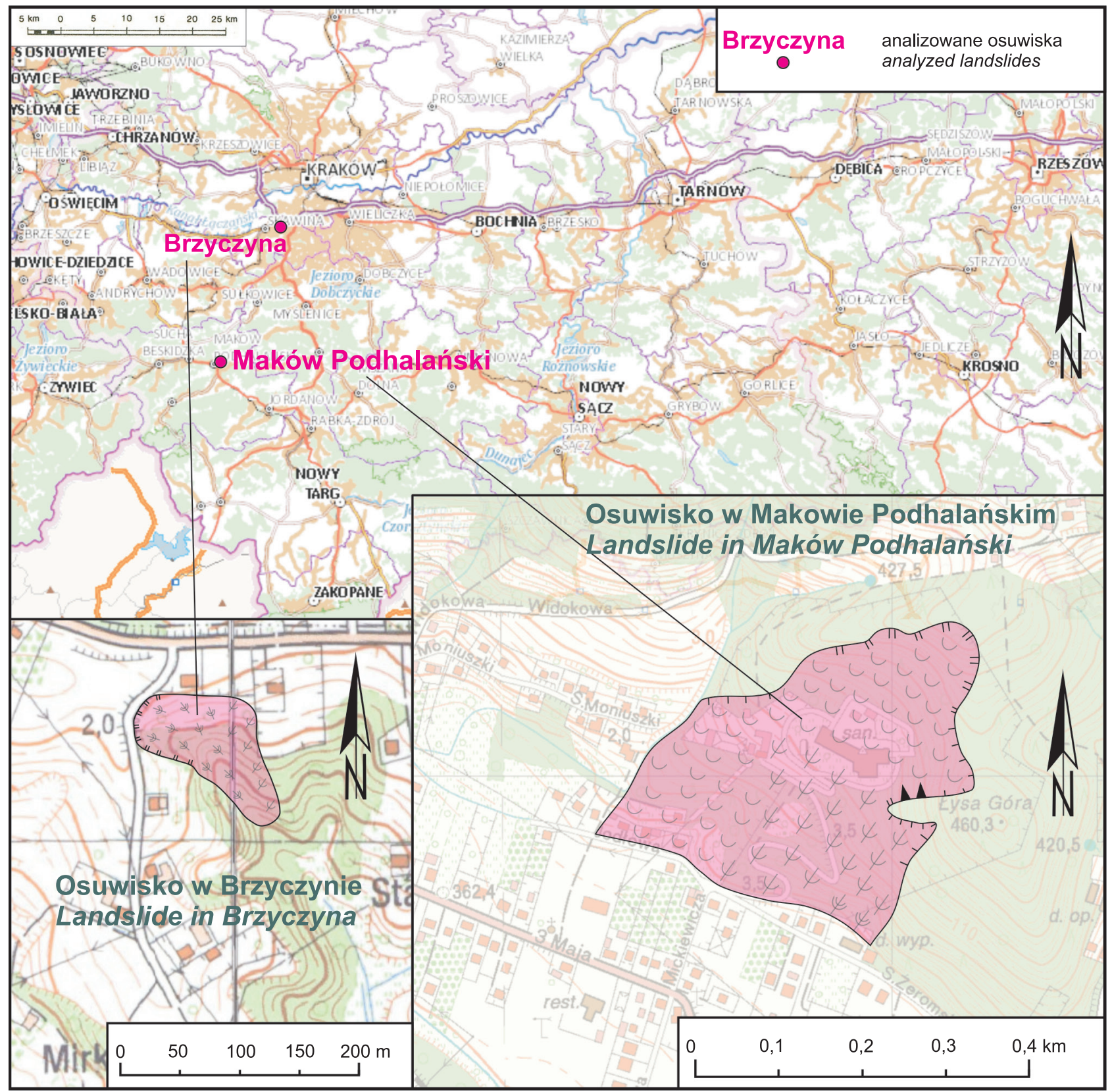

Ryc. 1. Lokalizacja osuwisk

Fig. 1. Location of landslides

bezpieczenia osuwiska ze względu na skalę rejestrowanych przemieszczeń i znaczne miąższości utworów koluwialnych.

Odmiennym przykładem jest osuwisko w Brzyczynie, gmina Mogilany, powiat krakowski-ziemski, w województwie małopolskim (ryc. 1, 5). Osuwisko rozwinęło się na stoku po wschodniej stronie drogi gminnej, która na odcinku ok. 100 m uległa częściowemu uszkodzeniu. Obok skarp bocznych po dwóch stronach osuwiska znajdują się budynki mieszkalne (ryc. 5).

Osuwisko propagowało w obrębie starszej formy osuwiskowej występującej w leju źródłowym potoku bez nazwy, wykorzystującego dyslokacje tektoniczną. Teren osuwiska w przeszłości został zasypany odpadami pobudowlanymi przez okoliczną ludność. Dociążenie górnej części stoku, jego niekorzystna geometria oraz infiltracja opadów atmosferycznych doprowadziły do uaktywnienia procesów osuwiskowych.

Górna część osuwiska zaznacza się cylindryczną skarpą główną o wysokości 3-5 m, obejmującą część drogi gminnej, a jego powierzchnia zwęża się w dół stoku. Teren całego osuwiska pokrywają liczne nierówności, pęknięcia, szczeliny oraz stawy wewnątrzosuwiskowe. W centralnej części występują podmokłości, a w górnej - sączenia wypływające ze skarpy głównej osuwiska. Ze względu na powstałe deformacje terenu, rozpadliny i otwarte szczeliny, osuwisko sklasyfikowano jako aktywne i okresowo aktywne (ryc. 5).

Koluwia osuwiskowe to nawodnione grunty nasypowe, gliny piaszczyste, gliny pylaste, gliny zwięzłe oraz iły pylaste i iłołupki o miąższości od $5 \mathrm{~m}$ w otworze O-1 do 14,5 m w otworze O-4 (Kos i in., 2012) (ryc. 6). Rozpoznano dwie powierzchnie poślizgu. Pierwsza jest po- 


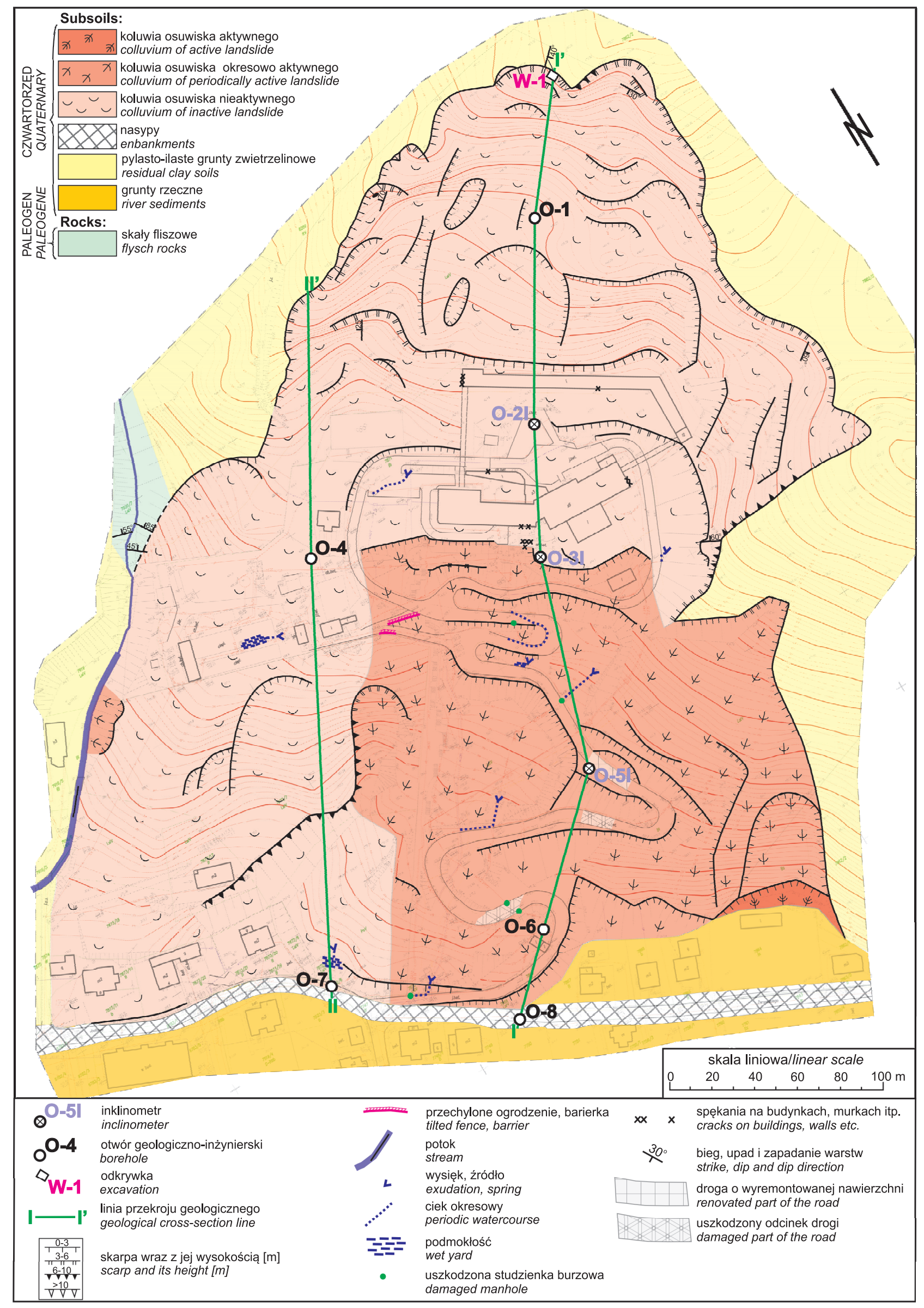

Ryc. 2. Mapa geologiczno-inżynierska osuwiska w Makowie Podhalańskim

Fig. 2. Geological-engineering map of landslide in Maków Podhalański 


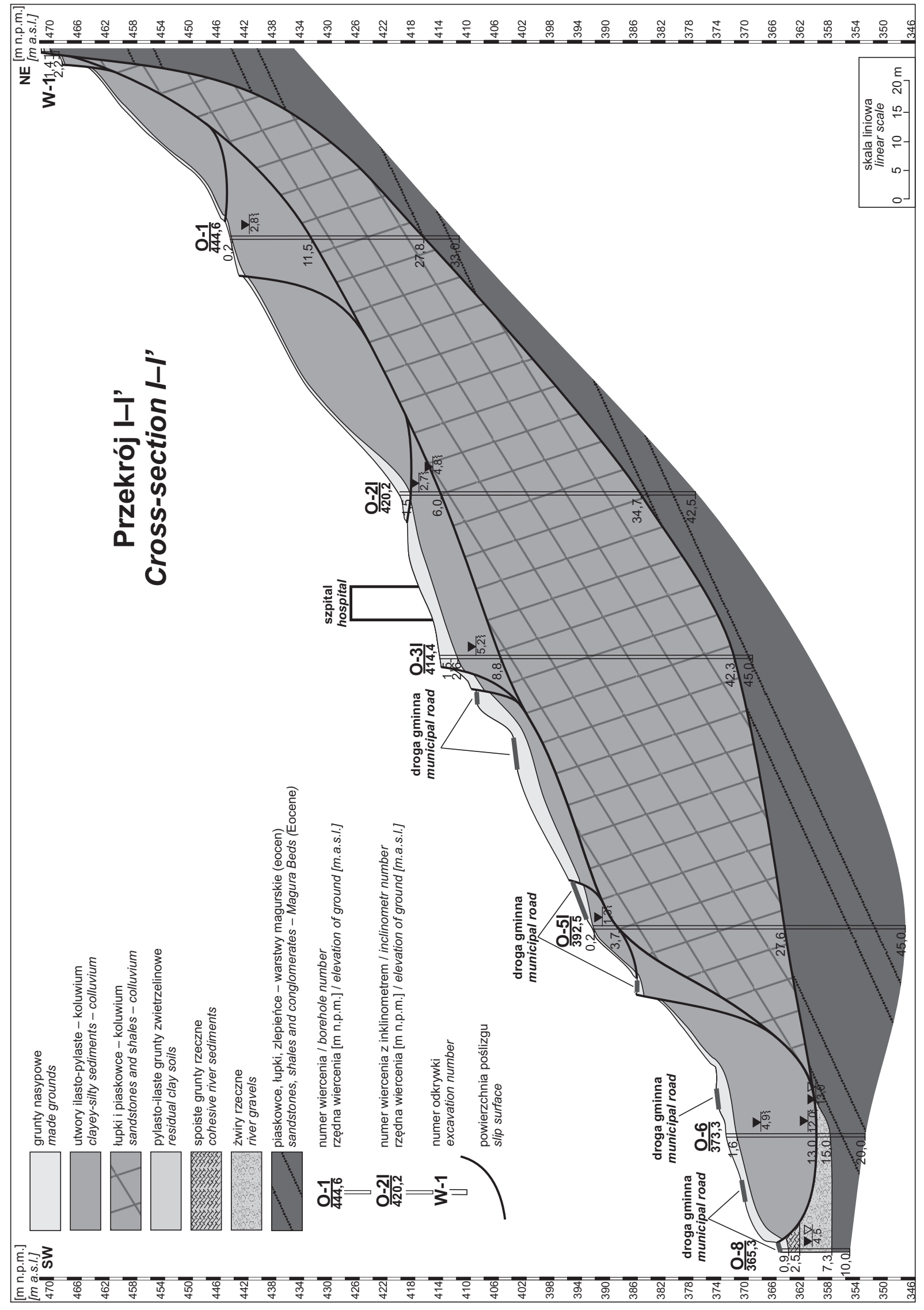

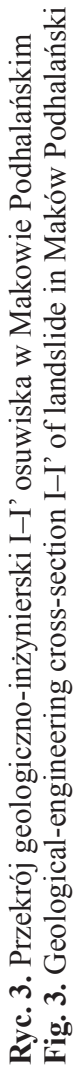




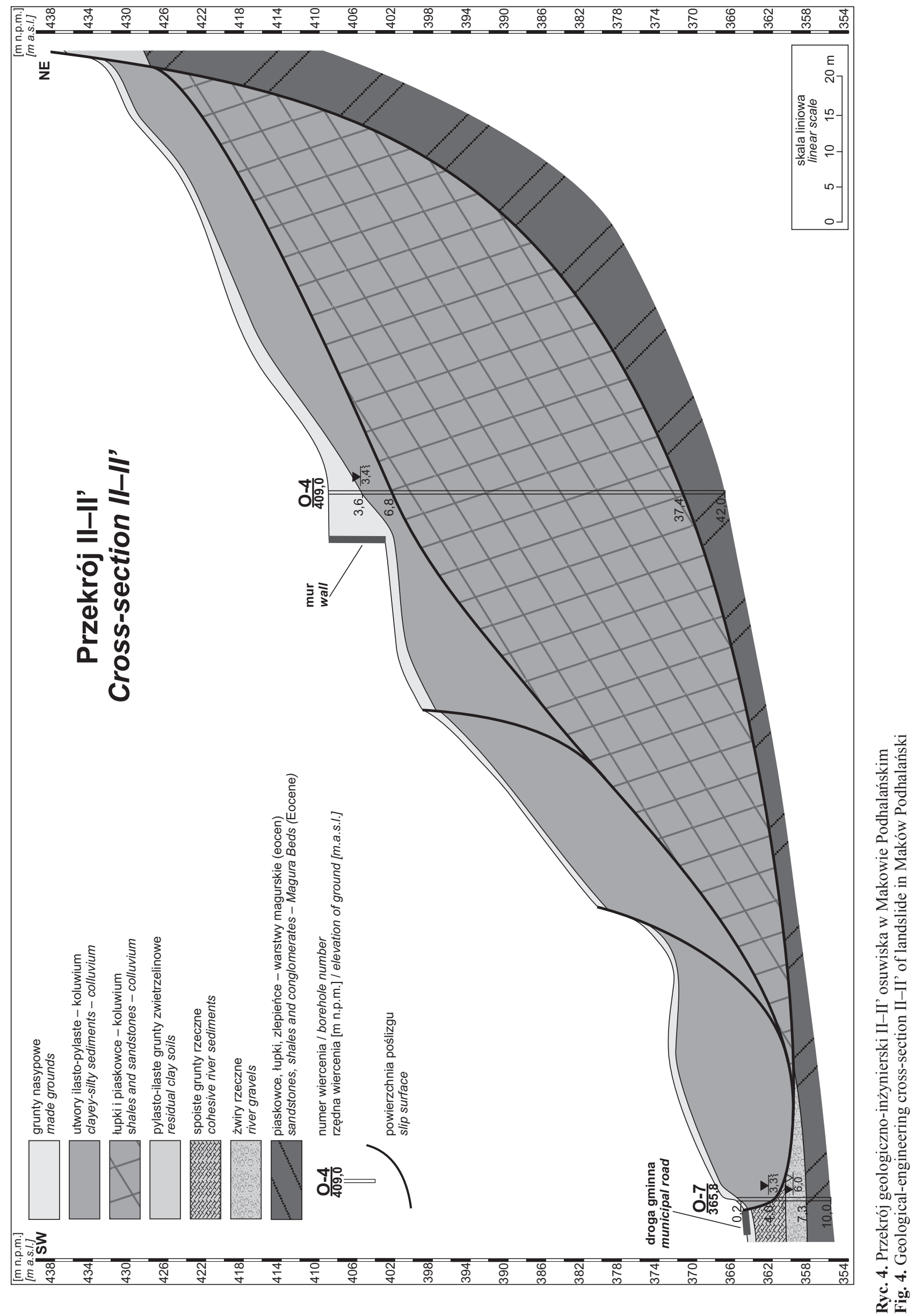




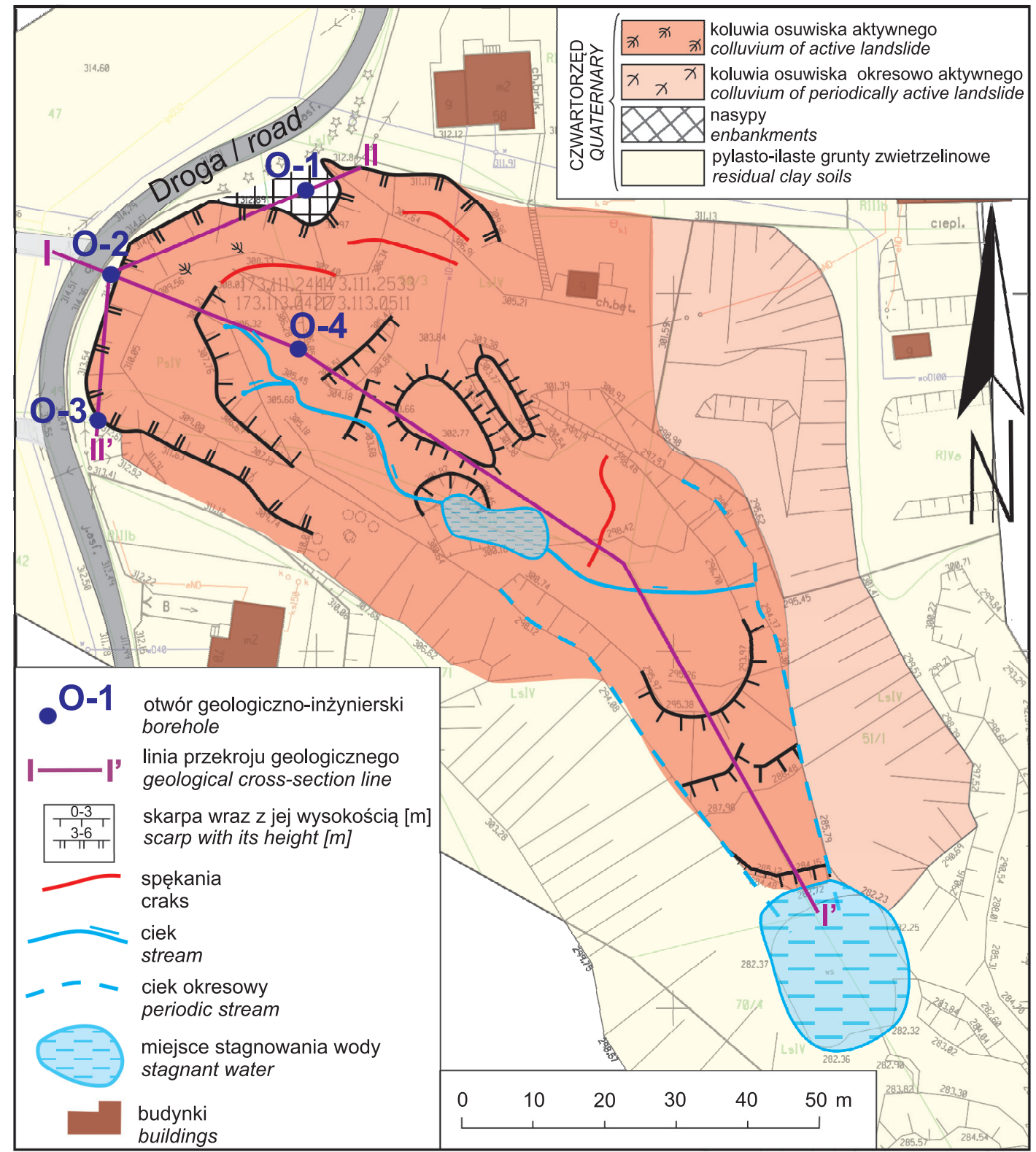

Ryc. 5. Mapa geologiczno-inżynierska osuwiska w Brzyczynie Fig. 5. Geological-engineering map of landslide in Brzyczyna

wierzchnią aktywną i przebiega na głębokości $8,3 \mathrm{~m}$ p.p.t. w otworze O-4 po stropie iłołupków oraz na głębokości $5 \mathrm{~m}$ p.p.t w otworze O-1 w spągu plastycznych glin pylastych. Druga powierzchnia poślizgu jest nieaktywna i w otworze O-4 przebiega na głębokości 14,5 m p.p.t. w warstwie iłołupków (ryc. 6).

Osuwisko w Byczynie jest przykładem średniego osuwiska, którego rozpoznanie skupiło się przede wszystkim w rejonie skarpy głównej, gdzie zabezpieczono drogę gminną. Szczegółowe rozpoznanie w rejonie skarpy głównej pozwoliło na wybranie rodzaju konstrukcji zabezpieczającej i wykonanie odwodnień.

W przypadku wykonywania dokumentacji geologiczno-inżynierskich dla osuwisk małych o powierzchni do 10 arów, ich rozpoznanie ogranicza się do wykonania najczęściej jednego wiercenia rdzeniowanego w rejonie uszkodzonej infrastruktury oraz odkrywki. Są to najczęściej skarpy przykorytowe utworzone przez erozję boczną.
Roboty geologiczne są prowadzone wzdłuż osi osuwiska aby określić głębokość aktywnej i najgłębszej powierzchni poślizgu.

\section{PROCEDURY DOKUMENTOWANIA OSUWISK}

Projektowanie wierceń geologiczno-inżynierskich należy uzależnić od skali osuwiska i przewidywanego jego zagospodarowania. W przypadku prowadzenia inwestycji liniowych dla dużych osuwisk sztywne założenie rozstawu wierceń nad skarpą główną i poniżej czoła osuwiska może nie wnosić dodatkowych informacji i być ekonomicznie nieuzasadnione. Przedstawione przykłady osuwisk dokumentują powierzchnie poślizgu i pozwalają na wykonanie konstrukcji zabezpieczających oraz odwodnienia powierzchniowego i wgłębnego. W nawiązaniu do procedur zabezpieczania obszarów osuwiskowych (Wójcik i in., 2017) w pierwszym kroku dokumentowania obszaru osu- 


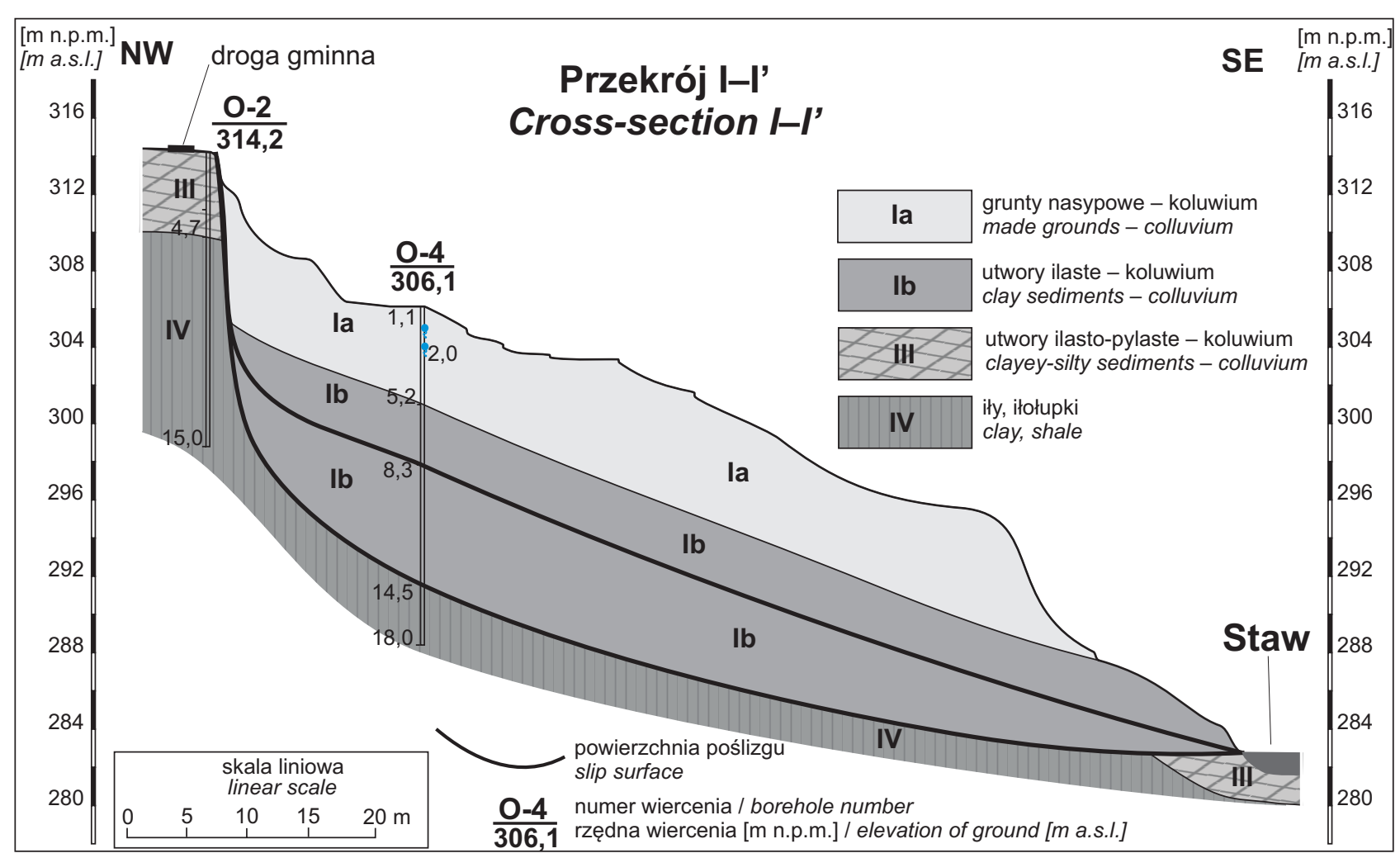

Ryc. 6. Przekrój geologiczno-inżynierski I-I' osuwiska w Brzyczynie

Fig. 6. Geological-engineering cross-section I-I' of landslide in Brzyczyna

wiskowego należy wykonać kartę dokumentacyjną z opinią. Po przeprowadzeniu przez inwestora analizy ekonomicznej w koordynacji z jednostką geologiczną (PIG-PIB) należy przeprowadzić szczegółowe badania geologiczno-inżynierskie. Ich zakres powinien być uzależniony od wielkości badanego osuwiska oraz wpływu jego uruchomienia na potencjalne uszkodzenia/zniszczenia istniejących obiektów budowlanych oraz infrastruktury technicznej/drogowej. Dla terenu osuwiska powinna zostać wykonana mapa sytuacyjno-wysokościowa w skali $1: 500$ lub $1: 1000$, na której należy przedstawić szczegółowe wyniki z kartowania geologiczno-inżynierskiego osuwiska i jego strefy buforowej. Otwory badawcze powinny być lokalizowane w osi osuwiska w taki sposób, aby można było skonstruować przekrój podłużny przechodzący od skarpy głównej po czoło osuwiskowe, co zobrazowano na przedstawionych przykładach osuwisk. Dobrą praktyką dla dużych osuwisk powinny być przynajmniej dwa-trzy przekroje podłużne prowadzone przez cały obszar osuwiskowy oraz przekroje poprzeczne, które uszczegóławiają rozpoznanie obszaru osuwiskowego danymi z kartowania geologiczno-inżynierskiego. Ważną kwestią przy rozpoznawaniu osuwisk jest technika prowadzonych wierceń.

Jedynie wiercenia pełnordzeniowe pozwalają w sposób wiarygodny zidentyfikować i określić głębokości występowania powierzchni ścięcia, po których wystąpiło przemieszczenie koluwiów osuwiskowych. Podczas wierceń należy na bieżąco oceniać pozyskiwany rdzeń, którego uzysk nie powinien być mniejszy niż 85\%. Wiercenia należy prowadzić do głębokości minimum 3-5 m poniżej najniższej stwierdzonej powierzchni poślizgu. Kwestią dys- kusyjną w większości przypadków jest głębokość na jakiej należy zakończyć wiercenia. Geolog dokumentujący na bieżąco powinien oceniać uzyskiwany rdzeń, analizować stwierdzone powierzchnie ścięcia i na tej podstawie określać ostateczną głębokość wiercenia. W projekcie robót geologicznych dla terenów osuwiskowych należy przewidywać rezerwę na przegłębienie planowanych wierceń. Na przykładzie analizowanych głębokich osuwisk strukturalnych obejmujących przemieszczone pakiety skalne fliszu zwraca się szczególną uwagę na właściwe pobieranie próbek do badań laboratoryjnych. Kwestią zasadniczą jest pobieranie ich z rejonów występowania stref osłabień oraz stwierdzonych powierzchni ścięcia (zlustrowań). Bardzo częstym błędem jest wykonywanie badań wytrzymałościowych próbek skalnych, które uległy przemieszczeniu w pakietach skalnych. W tym wypadku należy oceniać jakość masywu skalnego. Badania próbek skalnych należy wykonywać przy strefach stwierdzonych powierzchni ścięcia. Wzdłuż osi osuwiska w nawiązaniu do odwierconych otworów badawczych należy wykonać badania geofizyczne, np. tomografię elektrooporową.

Po przeprowadzeniu badań terenowych i laboratoryjnych należy opracować przekroje obliczeniowe wzdłuż osi osuwiska i określić parametry na podstawie badań labortoryjnych lub przyjąć parametry eksperckie dla poszczególnych warstw geologiczno-inżynierskich. Uzyskane wyniki pozwolą na opracowanie modelu obliczeniowego do przeprowadzenia analiz stateczności zbocza osuwiskowego. Im bardziej szczegółowo zostanie rozpoznane podłoże tym wykonana analiza stateczności będzie dokładniejsza i bardziej wiarygodna. Odpowiednie przeprowadzenie analiz 
będzie jednoznaczne z właściwym udokumentowaniem obszaru osuwiskowego. Nie powinno się wykonywać obliczeń dla przekrojów konstruowanych z jednego wiercenia badawczego czy też danych uzyskanych np. z parametrów normowych. Uzyskane wyniki dla takich obliczeń są najczęściej obarczone znacznym błędem w określeniu wskaźnika stateczności.

Monitoring powinien stanowić uzupełnienie przeprowadzonych badań terenowych i oceniać skalę przemieszczeń, która powinna zostać określona w pierwszym etapie. Skalę przemieszczeń określa się przez pomiary inklinometryczne, które pozwalają zweryfikować założenie przyjęte do obliczeń. Wielkość przemieszczeń powinna być także wykorzystana podczas opracowywania projektu budowlanego zabezpieczeń obszaru osuwiskowego.

Zwraca się uwagę na właściwy opis skał podłoża osuwiska, ponieważ zbyt płytkie rozpoznanie geologiczne jest najczęstszą przyczyną błędnego dokumentowania geologiczno-inżynierskiego osuwisk i terenów zagrożonych ruchami masowymi (Wójcik, 2015; Wójcik i in., 2017). Taki sposób dokumentowania z właściwą techniką wierceń pełnordzeniowanych pozwala na wyeliminowanie błędów zbyt płytkiego czy też niewłaściwego rozpoznania podłoża na obszarach osuwiskowych. Jest on rekomendowany do prowadzenia badań szczególnie na terenie fliszu karpackiego.

W związku z powyższym postuluje się wprowadzenie zmian w prawie geologicznym dotyczących wykonywania dokumentacji geologiczno-inżynierskich dla osuwisk.

Propozycja rozszerzenia zakresu rozporządzenia Ministra Środowiska z dnia 18 listopada 2016 r. w sprawie dokumentacji hydrogeologicznej i geologiczno-inżynierskiej (Rozporządzenie, 2016) dla dokumentacji geologiczno-inżynierskiej na podstawie zabezpieczenia osuwisk oprócz elementów wymienionych $\mathrm{w} \S 19$ ust. 1 zawiera ponadto:

- opis rdzeni wiertniczych z identyfikowanymi powierzchniami ścięcia oraz strefami zlustrowań,

- ocenę stateczności osuwiska i terenu zagrożonego ruchami masowymi wraz z analizą ryzyka uruchomienia powierzchniowych ruchów masowych po wykonaniu inwestycji,

- obliczenia stateczności przynajmniej w jednym przekroju obliczeniowym zlokalizowanym w osi osuwiska,

- ocenę warunków wodnych na obszarze osuwiska i terenu zagrożonego ruchami masowymi wraz z określeniem wpływu wody na możliwość ich uaktywnienia,

- wytyczne odnośnie lokalizacji projektowanego odwodnienia terenu $\mathrm{z}$ określeniem jego rodzaju i proponowanej głębokości usytuowania w przypadku drenażu wgłębnego,

- rodzaj i zakres proponowanego monitoringu osuwiska w trakcie prowadzenia robót budowlanych i po ich wykonaniu.

\section{PODSUMOWANIE I WNIOSKI}

Jednym z głównych czynników wpływających na stateczność stoków osuwiskowych jest nawodnienie gruntów. Nasilenie ruchów osuwiskowych obserwowane na przestrzeni lat następuje w okresach długotrwałych opadów at- mosferycznych. Na skutek infiltracji wód w podłoże dochodzi do redukcji parametrów wytrzymałościowych, szczególnie w utworach spoistych z licznymi okruchami skalnymi oraz zwiększenia ciężaru podatnych na zsuw mas skalnych.

Podczas prowadzenia badań geologicznych na terenach osuwiskowych istotną kwestią jest określenie zakresu projektowanych robót geologicznych. Najważniejszym zagadnieniem przy badaniu osuwisk jest rozpoznanie głębokości przebiegu i kształtu powierzchni poślizgu. Wymaga to wykonania odpowiedniego rodzaju wierceń i uzyskania dobrej jakości rdzenia. Najczęściej w obrębie jednego osuwiska dokumentuje się kilka powierzchni poślizgu, które występują na różnych głębokościach, co wiąże się ze złożonym sposobem ruchu i ścinania. Przeważnie są to przebiegające głęboko powierzchnie poślizgu o kształcie cylindrycznym lub szuflowym.

Właściwe określenie aktywnych i najgłębiej zalegających powierzchni poślizgu pozwala na skonstruowanie modelu obliczeniowego i dobranie optymalnej metody zabezpieczenia terenu osuwiskowego. Przebieg powierzchni poślizgu często nie jest determinowany głębokością zalegania podłoża skalnego pod utworami pokrywowymi. Rozpoznanie geologiczne powinno być uzależnione od wielkości badanego osuwiska oraz wpływu jego uruchomienia na potencjalne uszkodzenia/zniszczenia istniejących obiektów budowlanych oraz infrastruktury technicznej.

Przedstawiony powyżej sposób dokumentowania i prowadzenia obliczeń jest rekomendowany na terenach osuwiskowych. W pierwszym kroku należy przeprowadzić obliczenia na podstawie danych uzyskanych z prac terenowych oraz parametrów otrzymanych z badań laboratoryjnych. Monitoring powinien stanowić uzupełnienie badań terenowych i oceniać skalę przemieszczeń.

Częstotliwość pomiarów inklinometrycznych jest uzależniona od stopnia aktywności terenu osuwiskowego oraz rodzaju zagrożeń. Pomiary powinno się wykonywać przynajmniej raz na kwartał po zainstalowaniu kolumny inklinometrycznej. Po rocznej obserwacji kolumny inklinometrycznej, w zależności od stwierdzonych wielkości przemieszczeń, częstotliwość pomiarów można ograniczyć. Pomiary powinno się także prowadzić po długotrwałych lub intensywnych opadach atmosferycznych. Monitoring powinien być prowadzony w celu określenia wielkości przemieszczeń wzdłuż powierzchni poślizgu i na podstawie stwierdzanych wartości liczbowych powinna być oceniana skala zagrożenia obszaru osuwiskowego.

Prowadzenie obliczeń stateczności powinno być standardem przy wykonywaniu dokumentacji geologiczno-inżynierskich osuwisk i terenów zagrożonych ruchami masowymi. Pozwala ono na ocenę ryzyka i zagrożenia dla projektowanej inwestycji, czy też konstrukcji zabezpieczającej. Obecnie geolodzy w większości wypadków przeprowadzają taką analizę na podstawie dostępnych map z systemu SOPO. Analiza ryzyka uruchomienia osuwiska odbywa się najczęściej poprzez określenie aktywności obszaru osuwiskowego i to ryzyko wzrasta wraz z aktywnością osuwiska. 
Takie podejście jest uproszczeniem. Należy szczegółowo analizować morfologię terenu, rodzaj gruntów występujących w podłożu, a przede wszystkim prowadzić analizy numeryczne, które wskażą rzeczywistą skalę zagrożeń dla projektowanego obiektu.

Projekty budowlane wykonywane dla obiektów na osuwiskach także w wielu wypadkach nie zawierają obliczeń stateczności zbocza. Często wynika to z braku danych. Nawet dla wierceń rdzeniowanych często nie są wykonywane badania wytrzymałościowe, które są podstawą do przeprowadzenia nawet uproszczonych analiz stateczności.

W związku z tym należy zmodyfikować prawo geologiczne, aby nie dochodziło do sytuacji uszkodzeń obiektów budowlanych, które zaprojektowano na podstawie niepewnych danych geologicznych. Postuluje się modyfikację rozporządzenia $\mathrm{w}$ sprawie wykonywania dokumentacji geologiczno-inżynierskich o dodanie punktu dotyczącego dokumentowania osuwisk. W przypadku występowania takiego obszaru należy spełnić wymogi specjalne stawiane dla obszarów osuwisk.

Autorzy serdecznie dziękują panu Zbigniewowi Bestyńskiemu i drugiemu anonimowemu Recenzentowi za cenne uwagi i wskazówki, które wpłynęły na ostateczną wersję artykułu.

\section{LITERATURA}

BOBER L. 1984 - Rejony osuwiskowe w polskich Karpatach fliszowych $\mathrm{i}$ ich związek z budową geologiczną. Biul. Inst. Geol., 340 (23): 115-153. CHOWANIEC J., WÓJCIK A. (red.) 2012 - Osuwiska w województwie małopolskim - atlas, przewodnik. Dep. Środ., Rol. i Geod. Urz. Marsz., Zespół Geologii. Kraków.

FRANKOWSKI Z., GODLEWSKI T., IRMIŃSKI W., ŁUKASIK S., MAJER E., NAŁECZ T., SOKOŁOWSKA M., WOŁKOWICZ W., CHADA K., CHOROMANSSKI D., GAŁKOWSKI P., JAŚKIEWICZ K., JURYS L., KACZYŃSKI Ł., MADEJ M., MAJER K., PIETRZYKOWSKI P., SAMEL I., WSZĘDYRÓWNY-NAST M. 2012 - Zasady dokumentowania warunków geologiczno-inżynierskich dla potrzeb rekultywacji terenów zdegradowanych. Min. Środ., Warszawa.

GRABOWSKI D., MARCINIEC P., MROZEK T., NESCIERUK P., RĄCZKOWSKI W., WÓJCIK A., ZIMNAL Z. 2008 - Instrukcja opracowania Mapy osuwisk i terenów zagrożonych ruchami masowymi w skali $1: 10$ 000. Państw. Inst. Geol., Warszawa.

INSTRUKCJA 1999 - Instrukcja obserwacji i badań osuwisk drogowych. Generalna Dyrekcja Dróg Publicznych.

KOS J. 2019 - Stateczność stoków osuwiskowych na podstawie pomiarów inklinometrycznych oraz właściwości fizyczno-mechaniczne skał i gruntów na przykładzie osuwisk w Ochojnie i Starym Sączu. Prz. Geol., 67 (5): 377-387.

KOS J., JASKÓLSKI Z., FORYŚ M., BARTOSZ L., KORZEC K. 2012 - Dokumentacja geologiczno-inżynierska dla stabilizacji osuwiska i odbudowy drogi gminnej nr K600614 (działka nr 49) na długości około $100 \mathrm{~m}$ (początek osuwiska około $30 \mathrm{~m}$ od drogi powiatowej nr K2174). Przedsiębiorstwo Geologiczne S.A., Kraków. Opracowanie archiwalne, CBDG nr 995742.

KOS J., JASKÓLSKI Z., FORYŚ M., SZYMONIK L., JĘDRZEJOWSKA M. 2016 - Dokumentacja geologiczno-inżynierska zespołu osuwiskowego w Makowie Podhalańskim. Przedsiębiorstwo Geologiczne S.A., Kraków. Opracowanie archiwalne, CBDG nr 1064718.
MIGOŃ P., KASPRZAK M. 2011 - Morfologiczny zapis ruchów masowych na progach morfologicznych Gór Stołowych w świetle numerycznego modelu wysokości o dużej rozdzielczości. Przyr. Sud., 14: 115-124. MIGOŃ P., JANCEWICZ K., KASPRZAK M. 2014 - Zasięg obszar objętych osuwiskami w górach Kamiennych (Sudety Środkowe) - porównanie map geologicznych i cyfrowego modelu terenu wysokości z danych LiDAR. Prz. Geol., 62 (9): 463-471.

NESCIERUK P. 2015 - Instrumentalny monitoring osuwisk. Ogólnopolska Konferencja O!suwisko, 19-22 maja 2015, Wieliczka. Materiały konferencyjne: $81-82$.

NESCIERUK P. 2017 - Błędy pomiarów inklinometrycznych. Ogólnopolskie Sympozjum współczesne problemy geologii inżynierskiej w Polsce, 17-20.10.2017, Rzeszów.

NESCIERUK P., RĄCZKOWSKI W. 2012 - Monitoring wgłębny osuwisk karpackich. II Polski Kongres Geologiczny, Warszawa.

PINIŃSKA J. 2003 - Strukturalne uwarunkowania mechanizmów rozciągania i ścinania w skałach osadowych fliszu karpackiego. Materiały II Sympozjum Mechaniki Zniszczenia Materiałów i Konstrukcji, 4-7 czerwca 2003, Augustów: 311-314. Polit. Białost.

PINIŃSKA J. 2004 - Właściwości wytrzymałościowe i odkształceniowe skał. Część IV Karpaty fliszowe. Objaśnienia i interpretacja. Zakład Geomechaniki Inst. Hydrog. i Geol. Inż., Wydz. Geol. Uniw. Warszaw.

PINIŃSKA J. 2007 - Szczelinowatość masywów skalnych po 30 latach w świetle normy PN-EN ISO 14689-1 - badania geotechniczne, rozpoznanie i klasyfikacja skał. GEOLOGOS, 11: 43-57.

POLSKA NORMA PN-EN 1997-1 Eurokod 7. Projektowanie geotechniczne. Część 1: Zasady ogólne.

POLSKA NORMA PN-EN 1997-2 Eurokod 7. Projektowanie geotechniczne. Część 2: Rozpoznanie i badanie podłoża gruntowego.

POPRAWA D., RĄCZKOWSKI W. 2003 - Osuwiska Karpat. Prz. Geol., 51 (8): 685-692.

RACZKOWSKI W. 2015 - Historia rozpoznania osuwisk i aspekty prawne. Materiały konferencyjne, Ogólnopolska Konferencja O!suwisko 19 22 maja 2015, Wieliczka. Materiały konferencyjne.

ROZPORZĄDZENIE, 2016 - Rozporządzenie Ministra Środowiska z dnia 18 listopada 2016 r. w sprawie dokumentacji hydrogeologicznej i geologiczno-inżynierskiej (Dz.U. 2016 poz. 2033).

SIKORA R., WOJCIECHOWSKI T. 2019 - Osuwiska w Sudetach. Prz. Geol., 67 (5): 360-368.

STRONA INTERNETOWA https://www.pgi.gov.pl/osuwiska/sopo-baza-wiedzy/6330-metody-wglebne.html.

TURNER A.K., SCHUSTER R.L. 1996 - Landslides investigation and mitigation. Special Report 247. National Academy Press Washington, D.C. WOJCIECHOWSKI T., 2019 - Podatność osuwiskowa Polski. Prz. Geol., 67 (5): 320-325.

WÓJCIK A. 2015 - Błędy rozpoznania i zabezpieczenia - czyli jak nie należy wykonywać prac stabilizacyjnych. Ogólnopolska Konferencja O!suwisko 19-22 maja 2015, Wieliczka. Materiały konferencyjne: 82-83. WÓJCIK A., KOS J. 2017 - Osuwiska i zagrożenie budowli inżynierskich - sukcesy i porażki przy stabilizacji osuwisk w świetle wierceń i obserwacji inklinometrycznych na przykładzie Sadowia, Kąclowej i Kopca Kościuszki. XXXII Ogólnopolskie warsztaty pracy projektanta konstrukcji, Wisła.

WÓJCIK A., KOS J., JURCZAK S. 2017 - Rozpoznanie i próby zabezpieczenia osuwiska w Kurowie (Pogórze Rożnowskie, Karpaty Zewnetrzne). Prz. Geol., 65 (9): 576-585.

WÓJCIK A. (red.), KAMIENIARZ S., WÓDKA M., BIAJGO A., JANECZEK A., WALATEK M. 2019 - Atlas osuwisk miasta Krakowa. Urząd Miasta Krakowa.

WYSOKIŃSKI L. 2011 - Ocena stateczności skarp i zboczy. Zasady wyboru zabezpieczeń. Wydaw. ITB, Warszawa.

WYTYCZNE 2016 - Wytyczne badań podłoża gruntowego dla potrzeb budowy i modernizacji infrastruktury kolejowej. PKP PLK S.A., Warszawa. ZABUSKI L., 2013 - Ocena procesów osuwiskowych na podstawie wyników pomiarów inklinometrycznych. Prz. Geol., 61 (4): 248-256.

ZABUSKI L., KULCZYKOWSKI M. 2020 - Współczesne procesy osuwiskowe na klifie w Jastrzębiej Górze. Prz. Geol., 68 (9): 682-690.

Praca wpłynęła do redakcji 31.05.2021 r. Akceptowano do druku 19.07.2021 r. 